\title{
The Idea of Space among the Nomads of Great Steppe
}

\author{
Marina M. Sodnompilova \\ Institute for Mongolian, Buddhist and Tibetan Studies of the \\ Siberian Branch of the Russian Academy of Sciences, \\ Ulan-Ude
}

\author{
Bair Z. Nanzatov \\ Institute for Mongolian, Buddhist and Tibetan Studies of the \\ Siberian Branch of the Russian Academy of Sciences, \\ Ulan-Ude
}

\begin{abstract}
Nomads were the Mongolic and Turkic peoples that inhabited vast territories of Inner Asia, including natural areas from the desert to the tundra, from highlands to steppe plains. The development of this diverse space is one of the debated issues in the history of nomadic societies, which still remains relevant. A wide range of ecological zones led to the formation of a rich worldview which created mythological, ethnic, and symbolic images of spaces. For each particular natural zone there was formed a particular mechanism for comprehending and developing territories.
\end{abstract}

\section{INTRODUCTION}

A system of concepts of the world and the humanity's place in it is one of the most important conditions for the human adaptation to the natural environment. The world of nomads is traditionally viewed by researchers as a constant barbaric threat to the civilized agricultural world. It is also regarded as a territory. This largely negative image of the nomads as a 'natural disaster' or 'biblical punishment' (Braudel 1994: 164-168) is explained by the harsh environmental conditions in the nomad-settled territories, which made them unattractive to farmers. Interest in these territories and their images, particularly those created by the nomads themselves, has yet to become a focus of special research.

The nomadic Mongols and Turks settled across the vast Inner Asian expanse, embracing natural zones from desert to tundra and from highSocial Evolution \& History, Vol. 18 No. 2, September 2019 35-54 
lands to flat steppes. Their exploitation of this heterogeneous space has been one of the most topical issues in the history of nomadic societies and it remains so today. A broad range of environmental 'niches' resulted in the shaping of a rich conceptual base, which produced mythological, ethnic and symbolic images of the expanses - the mechanism of understanding and exploitation of territories specific to each separate natural zone.

Presently, there exist a multitude of works on various aspects of extrabiological adaptation to the nomadic natural environment of Inner Asia. A considerable part of the studies concentrated on the nomads' linguistic vision of the world, without which understanding of a conceptual model of the world is impossible. The analysis of the pre-Turks lexicon carried out by the Turkologists under the supervision of Anna Dybo and Edkhiam Tenishev made it possible to reconstruct the natural habitat and lifestyle of the pre-Turks communities. Basing on ritual folklore texts, Lidia Skorodumova (2004) proposed a version of a Mongolian mythopoetic vision of the world. The interconnectedness of space exploitation practices in nomadic culture with the value orientations of society was shown on the basis of linguistic materials by Beffa and Hamayon (1983: 81-111).

Concrete exploitation and sacralization of geographical space is examined in these studies within the context of social, political and economic problems associated with the history of evolution of the nomadic empires (Barfield 1992, 2001; Di Cosmo 1994; Khazanov 1984; Kradin 2002), the social structure of nomadic communities (Humphrey 1974), or religion and concepts of authority and power. Geographical space and climatic conditions came to be understood as active milieus conducive to the development of a sort of civilizational self-awareness substantiating, in particular, an interaction strategy between the nomads and neighboring agricultural communities. For example, the most recent work by Nicola di Cosmo questions the established hypothesis about food crisis (crises?) in the steppes as the main factor (Jenkins 1974) that unleashed Chinggis-Khan's conquests (Di Cosmo 2015).

A whole set of research works is devoted to the Mongolian yurt, from typology and architectural specificities of this traditional dwelling (Maidar and Darisuren 1976; Egorov and Zhukovskaya 1979) to exploration of the idea that the yurt manifested models of the universe (Wasilewski 1976) and societal structure (Humphrey 1974). A broad range of such topics, including ones specific to the Turks-Mongolian peoples, was analyzed by Alexander V. Podosinov (1999).

For the purpose of this paper, the most significant works are those which explain the mechanism for space comprehension proposed by André Leroi-Gourhan (1965). Applied to the traditional culture and worldview of the Mongolian peoples they demonstrate that both linear and concentric principles of space exploitation are relevant to nomadic culture (Zhukovskaya 1988; Skrynnikova 2005). The experience of the emotional com- 
prehension of space is a pertinent research trend in this field of study. Its various aspects were studied in a series of research works by $\mathrm{Yu}-\mathrm{Fu}$ Tuan who introduced the 'topophilia' concept (Tuan 1974, 2002). John Robert Gold highlighted the significance of the concrete and sensuous orientation system at a local level (Gold 1980). The sensuous and religious experience of nomadic comprehension of space still remains a problem outside the main research focus. The existing studies of the Great Steppe's nomads overlook the important philosophical aspects of a connection between the nomads and space, thereby ignoring the nomadic sense of native land as well as their emotional, aesthetic and religious perception of space. Anatoly Khazanov related these aspects to a broad array of important, but still unstudied issues, noting the conscious limitation of his own studies by social, economic and political factors (Khazanov 2008).

In this context, this paper aims at investigating the symbolic comprehension of environment in the nomadic worldview, mostly in the Mongolian world, within the context of the real-life adaptation of the nomads to the diversity of their natural habitat. One form of the mental mastering of space is sacral topography, which presupposes a religious and mythological description of an area. In that regard, we are interested not only in sacral loci, but also in the motives for sacralization of the habitat. The images of native land (oron, nyutag) are woven into the fabric of mental exploitation of space as they are key markers of clan and tribal identity of nomads, which will be considered in detail later. The civilizational approach forms a natural conceptual framework for the study of adaptation strategies and practices developed by various traditions of the Mongolian world. We consider it productive to study the local knowledge of the nomads using geocivilizational approaches. They make it possible to view the concrete adaptation strategies of nomads to a certain natural environment from the standpoint of geodeterminism using material culture as example. The concept of geopossibilism will be used to demonstrate the flexibility and variability of the character of the local knowledge, which determines the range expansion of the modes of adaptation of nomads to environment. The spatial representations and the mechanisms of their formation and utilization in various aspects of nomadic life will be approached from the perspective of cognitive geography.

\section{THE IMAGE OF THE WORLD}

The nomadic worldview displays different numerical images of horizontal space. The models including both four basic and four interim sides act as a numerical scheme of space. They are complemented by other numerical images, such as 'heptagonal' and 'hexagonal land' (Burchina 1990: 168). This example evinces a special phenomenon related to perception of the world, in which simultaneously a model of the universe is reflected in the yurt (Wasilewski 1976), and the world around is perceived through 
the prism of dwelling. For the South Siberian Turks and Buryats a traditional wooden polygonal dwelling acted as a conceptual model of the world. Such an image of space is characteristic of the all-Turks model of the world in the early medieval epoch (Kyzlassov 1960: 51, 57) expressed in the formula 'tört bulun qop' - 'four corners of the world' (Malov 1959).

The social interpretation of space through the prism of traditional dwelling is ubiquitous in nomadic culture. Vadim V. Trepavlov described the ideal modeling of Fatherland as a dwelling, in which various localities are compared to different parts of the yurt among the nomads of Eastern Desht and the Nogais (Trepavlov 2011: 110). The organization of the yurt's interior space and its symbolism are reflected in the perception of the outer world by the Mongols. From this point of view on space, it is the part of the ayl settlement closest to the dwelling that is primarily conceptualized. ${ }^{1}$

Omens associated with the first spring thunderstorm represent another example of the conceptualization of the outer world from the perspective of this conceptual model. Interpretation of these omens was similar among both the Turks and Mongols. 'When the first thunder clap growls, they note on which side of the yurt it is better heard: if it is the female side - there will be a good milk yield; if it is the male side - then there will be abundant spoils of the chase, etc.' (Potanin 1883: 142).

Cisbaikalian toponyms contain the geographical name 'khoimor' (the most honorable part of a yurt). This is a common name for the northern part of a valley. Thus, Cisbaikalian toponymy data confirms the relevance of this vision of space.

\section{CARDINAL POINTS}

The southeastern and southern sectors are the most sacral direction for the Turks-Mongolian peoples. The sacredness of the southerly direction is intensified by the existence of a number of other natural environmental markers, including south-oriented landmarks (such as 'übür' - the southern treeless hill slopes, a characteristic feature of South Siberian and North Mongolian terrains) and the seasonal rhythms of wildlife (bird migrations). ${ }^{3}$ Alexander Podosinov reasonably suggested that the veneration of the south in the nomadic cultures of the Great Steppe reflected the influence of the highland Eurasian latitudinal belt (Podosinov 1999: 544). This complex of beliefs is supplemented by Evgeny V. Anichkov's hypothesis concerning northern peoples' recognition of the social significance of the rich ancient cultures of the South (Anichkov 1914). After the conversion of Mongols to Lamaism, their reverence of the south increased. It is likely that Buddhist images of the Sumeru mountain, Abbirati and the eternal dwelling place of ancestors located somewhere high in the far southern mountains were shaped in line with the positive perception of the south. 
The northern sector (or 'midnight side'), by contrast, has negative connotations. It is the realm of frost, night, and dreams; a land of malevolent deities and spirits. It also hosts the world of the dead. Images of frozen seas and desolate places from Buryat epic poems echo the real landscapes of northern territories. In terms of real geographical space, the South Siberian nomads considered lands in the lower reaches of Siberian rivers the land's end. This makes their perception of space akin to that of the 'forest peoples', such as the Evenki, Khanty, and Mansi. For the Buryats the Lena (bur. Qara Zulxe) was the river that marked the border with another world. Lake Baikal also invoked associations with the land's end among Transbaikalian Buryats and Mongols. ${ }^{4}$

An anthropocentric worldview that projects an image of a human body upon the world is a key idea in the nomadic milieu. In the context of this understanding of space, the right (baruun $^{5}$ ) and left (zuun) sectors of space acquire a special meaning. In the Mongolian tradition they conditionally overlap with the east-west axis. In our view, the west-east (eastwest?) axis is associated with images of the uncoiling nature of space/ world and the movement of the sun across the sky. The sun's route is tied to a range of positive ideas/images of life, mobility, and the dynamic exploitation of space. Within this context, the existence of certain spatial verbs representing movement along the east-west axis (zü̈̈lexe -'go eastward'; baruulaxa - 'go westward') in Mongolian languages is relevant. As a key idea, the concept of the world's uncoiling from east to west is reflected in the following description of Chinggis-Khan's victorious movement: '... conquered the world from sunrise to sunset' (Rintchen 1959: 69).

As a rule, this east-west axis was strictly observed when positioning yurts on camping grounds. The elder's yurt occupied the rightmost and foremost position. The principle part of the smoke flap ( $g o l-k e r n e l$, pivot), which was also a light source for a yurt, had to be oriented in the same manner. Gender differences implicit in the symbolism of right and left can also be 'read' in the 'text' of a landscape. Rivers flowing out of the right and left parts of space signify a benign locality. Camping in such places was thought to lead to the birth of a boy in some cases, and of a girl in others. If the rivers flowed in southerly or northerly directions a locality was viewed as unfavorable for settlement (Tserensodnom 2001: 482).

The spatial organization of a nomadic camp reflects the high social prestige of the rightmost and foremost parts of space occupied by the chieftain. His younger brothers placed their yurts further to the left, while sons settled behind. Thus, those settled behind and to the left of the chieftain form a group of 'insiders', blood kin through the father. ${ }^{6}$ The Kalmyks placed the tilt carts of widowed sisters and widowed daughters returning to father's clan, but already 'alien' to it, somewhat further to the south, that 
is, in the front, to the right from the central dwelling (Bakaeva and Sangadzhiev 2005: 57). According to Trepavlov, in the structure of nomadic empires, the further west located a ruler's residence the lower was his social status. It was explained by a visible decrease in sacrality from east to west (Trepavlov 2005: 81).

This part of space, settled by kinfolk of the settlement's chief, is simultaneously characterized as an 'internal ${ }^{17}$ locus in relation to the entire frontal/southern sector of space - the outer world.

\section{THE VERTICAL MODEL OF SPACE}

One meaningful result of the conceptualization of surrounding space is a reflection of the vertical vision of space in a horizontal plane. Contrasting landscape elements, such as various elevations and depressions in rough terrain, contributed to the shaping of such perceptions in people's worldview throughout different natural zones. A mountain-water opposition served as a constant in the vertical model of the world in the Mongolian mythopoetic view of the world, 'In a place with no mountains, where will water come from?' (Skorodumova 2004: 222). As for the practical utilization of space, rivers played an important role in the shaping of a vertical worldview. An analysis of linguistic material from the Turkic and Mongolian languages indicates that the vast majority of spatial terms is associated with the notions of 'up' and 'down' and, as a rule, they are combined with the flow directions of rivers. In accordance with the 'river scheme' space is split into 'upper' (effluent) and 'lower' (estuary) zones regardless of the cardinal points. In the Mongolian languages downstream or upstream movement was expressed by the spatial verbs: ügsexe - to go upstream, and uruudaxa - to go downstream.

\section{LANDSCAPE IMAGES}

The experience of adaptation to certain natural zones is preserved in the traditional worldview of the Mongolian peoples as symbolically rich images of space, reflecting the value orientations of nomads. These images primarily accumulate the concepts of homeland including the ideas of topophilic and topophobic spaces (Tuan 1974).

The classic type of nomadic husbandry based on the breeding of five species of cattle and a maximally intensive migration cycle could only be practiced in the space most suitable for living - on the plains of Inner Asia called gol gazar, xeer, or tala gazar. In the context of vitality the limitless expanse of steppes is associated with a long/infinite life. The steppedwelling Mongols preferred the boundless expanse, believing that a plain that was not limited by mountains longer sustained the lives of the elderly and positively impacted the youth. Cattle, such as horses, sheep, and camels, also preferred a vast flat steppe. 
The inhabitants of the Sayan highlands developed a different vision of a hospitable locality. Highlanders viewed a mountain valley as an inhospitable place as it was associated with a torn sack, leaking happiness. An ideal variant was a small enclosed mountain valley open only from the south. It needed to resemble a full bowl, symbolizing richness and well-being.

Mountain peaks were universally interpreted as features of a topophobic space. A reminiscent of a wolf's tooth, such landscapes implicitly carried associations of threat, misfortune, and deprivation. ${ }^{8}$ Forests played an important role in the lives of the Mongolian nomads. It was the 'rich Altai Khangai' whose pragmatic and spiritual functions intensified as the nomads moved further north. Woodlands of plains and highlands determined the economic activity cycles of northern nomads by limiting roaming time and territory as well as the species diversity of cattle. In the forest zone, nomads lived a semi-sedentary lifestyle, having mastered the construction of $\log$ houses in the shape of square, hexagonal and octagonal wooden Buryat yurts with domed roofs. The study of the genesis, typology, and building techniques of the south Siberian Turks dwellings, specifically of polygonal log buildings similar to the Buryat wooden yurt, connects their origins with the early Iron Age and explains such dwellings as an adaptation of the Turkic-speaking peoples to the forest-steppe landscape (Kyzlassov 2008: 310).

The development of horse herd farming and cattle breeding became a characteristic feature of animal husbandry in the forest-steppe zone. This economy was supplemented by a small number of sheep and goats. Deficits in sheep wool were balanced by items made from cattle hides (clothes, bedding, carpets). It is worth noting that the preponderance of horse and cattle bones over sheep bones in burials (e.g., Tologoy and Sayantuy) located on the taiga-steppe border has been traced as far back as the Neolithic period (Sosnovsky 1940: 140). Agriculture played an auxiliary role for the households in the forest-steppe zone. Buryats were sowing buckwheat and millet long before the arrival of Russians (Kudryavtsev 1940: 15). Later, however, when forced to pay tribute in fur, they abandoned agriculture and its importance declined. ${ }^{9}$ Lexical-semantic analysis of the names of crops in the Turkic and Mongolian languages indicates that barley and especially millet were the most ancient crops (Dybo 2008: 9). Hunting was of high practical value in the woodlands. Battues (zegete-aba / aba xaidag) in peacetime served as military drills to practice warrior skills. In addition, battues played a key role for Buryats, similar to traditional Mongolian assemblies, xuriltais and suglans, where the issues of import to all nomadic communities were discussed and settled.

Flora and fauna were the most obvious factors shaping ethnocultural difference in all times (Golovnev 1995: 42). In the nomadic world, these differences mostly manifest in people's attitude towards trees. The spiritual culture of northern Mongols and Turks - Buryats, Yakuts, and Khakas - 
is replete with floristic significance, which places them closer to other 'forest peoples' of Siberia, such as Evenks, Ugrians, and Samoyeds. There are various manifestations of complicity connection of tree and human in the Buryat culture. These include the existence of clan trees, associative connections of tree and society in maternity and funeral ritualism, and gendered associations. ${ }^{10}$ Since the roots of a tree determine the condition of its crown, it serves a symbol of generational continuity. A well-known Buryat saying reads, 'modonoi ündehen gazar dooduur, xünei ündehen - gazar deegüür' 'Tree roots (grow wide) underground, man's roots spread everywhere above the ground' (Galdanova 1997: 94). One of the most important markers manifesting sedentarization is a tethering post. A whole complex of important ritual activities aimed at conquering nature and exploitation of land is connected with the tethering post and wooden dwelling. Further to the south, in the steppes, high population mobility brings to naught practical and sacral significance of the tethering post.

The Inner Asian expanse inhabited by nomads is rich in rivers, lakes, and springs. Undoubtedly, these landscape objects were the subject of spiritual conceptualization by the region's inhabitants. Rivers (gol, müren, uhan/usun) alongside land form a well-known binomial 'gazar - usun' (land - water) through which the Mongolian peoples passed the image of the native land. A common question addressed to a stranger was 'where is the land you "fell to" (were born), and the water you drank?'

Turks-Mongolian peoples had drastically different views of 'slack water'/lakes (nuur/köl), or marshes (namag gazar) as a source of 'dead' water harmful to living beings, and the eternally moving water of rivers and springs. The studies of the Turkic languages show that the word for water as such is associated with running water; there is a multitude of terms denoting running water while there is a paucity of terms for slack water (Grammar... 2006: 379). The Turks particularly disliked wetlands. The Tuvinians believed that such places produced taint (bužaar) (Solomatina 2007: 163). The Buryats believed that marshes and lakes (wetlands in general) represented vents in the ground through which the land discharged exhaust gases. Such places were regarded as dangerous (bad) for human health.

Rivers served the major landmarks of an area, and 'kernels' of the local 'universe'. Aside from winter pastures, the entire cycle of nomadic roaming was tied to water sources. Rivers played an important role of transportation routes between distant areas during wintertime. Transportation links between remote or hard-to-access places, normally impossible in summertime, became possible in winter when the rivers froze over. Dry riverbeds were used by Mongolian caravaners as waymarks and transportation routes in the desert during wintertime. The highland and taiga landscapes are rich in various mineral springs all differing in temperature and 
chemical composition. Mineral spring water with strong healing properties occupied an important place in nomadic folk medicine.

The panoramic view from yurt doors, in which every trait of landscape was necessarily considered, was an important condition since the landscape view needed to be 'comforting' (Tserenkhand 1993: 34).

\section{ORGANIZATION OF A NOMADIC ROUTE}

Private property in the form of cattle and corporate property in the form of pastures formed the economic foundation of the nomadic world (Khazanov 2008). In the Buryat society pastures, along with hunting and fishing grounds were owned by communities and designated as 'clannish lands'. Winter pastures were excluded from communal ownership as they were the main loci of nomad territories and belonged to patronymies. Throughout the observable historical period in the nomadic society it was a younger son who inherited the winter camping ground including all household buildings and a dwelling. The inheritance tradition of the winter camping ground can largely be explained by the specific features of economic management in wintertime. A shortage of forage grasslands and harsh winter weather demanded a careful selection of locations for winter camping and did not allow for communal living of relatives or neighbors. According to a renowned Mongolian scholar G. Tserenkhand, the Mongolian winter camp was stationary unlike temporary summer (autumn and spring) camping grounds (Tserenkhand 1993: 35).

Roaming routes were family-inherited. Nomads roamed strictly along a route inherited from the ancestors within the borders of the 'clannish land'. This nomadic roaming route was unstable, though in general it adhered to certain camping grounds. Its spatial organization depended on many factors, from climatic to political and social. For instance, the roaming routes of the western Mongols changed with the death of someone in a family. 'They tried not to roam back to the old place for seven years, since they believed that the deceased had seven souls. One of those souls remained in the place where a person died' (Menes 1992: 122).

The four loci of a camping ground can be considered a common feature of an Inner Asian nomadic route: the winter, summer, autumn and spring camping sites. These are reflected in languages. However, lexical reconstruction data of the proto-Turkic language restores the image of people practicing distant-pasture cattle rearing with the predomination of horse breeding and two types of settlements - stationary winter and nomadic summer settlements (Dybo 2008: 8). The growing complexity of the roaming route is the result of the nomads' adaptation to particular environmental conditions and forage reserve as well as the increase in the species diversity of cattle and in the number of livestock. 
A camping site had to meet certain basic requirements, such as availability of grazing land, water, and fuel. Aside from wood, dung was also used as fuel.

The quality of pastures (bilčir) was the main deciding factor in the choice of area. When selecting grazing lands, nomads took into account a multitude of factors. They were aware of the useful and harmful qualities of the local flora and the needs of each species of cattle and they knew which places were rich in mineral substances. A selected camping site's flora was edible for all cattle species (Tserenkhand 1993: 33; Badamkhatan 2004: 13). In possession of deep knowledge regarding local climatic conditions, especially in desert zones, the nomads developed their roaming routes to avoid extremely arid places. Based on their life experience and longtime exposure to cycles of dry and wet weather, the Mongolian herders have the ability to immediately transform environmental conditions into 'resources' (Fernandez-Gimenez 2000; Marin 2010). Nicola di Cosmo considers this skill of the Mongolian herders an important military advantage during the expansion of the Mongolian empire alongside the mobility, discipline, and stamina of Mongolian warriors (di Cosmo 2017: 76).

Water sources are vital landscape elements, and they received special scrutiny. White and transparent river water with no discernible taste was assessed as high-quality water. Water running down a mountain was believed to bring lots of happiness if the mountains displayed some anthropomorphic traits, such as the shape of a mouth, ear, or breast. Choosing a site for a camp, Mongols paid attention to soil color, distinguishing between fertile and dead soils: surfaces that never changed color throughout the entire year marked the dead land (Tserensodnom 2001: 482).

In the forest zone nomads preferred to locate their settlements far from large wooded areas for fear of forest fires. Placement of a dwelling in the open was also necessary because all economic and everyday activity was timed according to the solar cycle and time was measured by the angle of incidence of a sun ray though the smoke flap of the yurt on parts of the dwelling and items of the interior. In the forest zone the connection with such types of landscape are apparent in the archaeological monuments of the Kurumchi (Qurumči) culture, which points at the cattlebreeding economic focus of the pre-Buryat tribes (Dashibalov 1995: 136).

Seasonal climatic conditions of various seasons are also among the most important factors to be taken into account while choosing a settlement site.

The nomads organized a system of grazing lands around the camping site with the account of peculiar features of the landscape and species diversity of the cattle. Pastures closest to the nomadic camp were reserved for young cattle, while those in the middle were for sheep, goats and cattle, and the farthest were left for the 'long haul' animals, such as horses and camels (Tserenkhand 1993: 32). Grazing time was also important: 
during summer nighttime was allocated to horses, while daytime was reserved for sheep, goats, and cattle.

\section{SACRALIZATION OF SPACE}

Throughout ancient times, a conceptual exploration of space was attained through the conceptualization of all objects filling the environment of the nomads, as well as all habitat zones. Focused exploration of territories is the dominant principle of space exploitation and a relevant specific mechanism of space sacralization (Leroi-Gourhan 1965). The intensity of economic activity (hunting and gathering, animal husbandry, and farming) differed among the Mongolian peoples. The (specific?) combination of various types of economic activity determined the highest degree of management of a territory. The space was represented by a network of sacral places relevant to various social communities (family, patronymy, tribe; hunters, priests, warriors, etc.).

During the early stages of space exploitation, the most remarkable landscape components, such as mountain peaks, cliffs, groves, and single trees served as landmarks, because they easily caught the human eye. Later, they turned into natural boundaries of the territories settled by communities of various levels - families, patronymies, clans, and tribes. Out of the diversity of landscape elements most attention was paid to mountains as vertical dominants of a geographical environment. Mountains became habitats for 'local hosts'. At various developmental stages of this cult, this role was played by 'both animals and ambivalent spirits of dead people, clan's ancestors, priests, shamans, military chieftains, rulers of various ranks' (Galdanova 1983: 118). The tradition to bury kinfolk, especially shamans, in the mountains was followed primarily to ensure a certain territory would be assigned to a certain ethnic community. According to Buryat beliefs, after death shamans and shamanesses 'became mountains' (xada bolod xuuha) and acquired a status of 'area's hosts'. Their burial places were marked by special signposts named barisa (tethering post) or sacred groves. They patronized each family and each person from their community.

Prominent mountains marking clannish territories were viewed by Buryats as the birthplace of a clan (clan's ancestor) or as a place where the 'motherly afterbirth of a clan' was buried (Baldaev 1959: 49). Stone sacrificial altars were erected at their tops and each year members of the community would gather there to offer sacrifice to deities and ancestors, or tailagan. Some sacred mountains had the status of tribal center. When they settled in new lands, the Buryats brought with them the sacrificial altar stones from their old cult places. In doing so, they sacralized a newly settled place. Usually such acts were carried out in secret, without the knowledge of fellow tribespeople, since the latter might perceive them as attempts to 'lure away the ancestral happiness' to the new place. 
The sacred mountains of the Turks-Mongolian peoples of South Siberia act not only as key symbols of their territories, they are also the 'face' of the individual communities, such as patronymies, clans, or tribes, that dominate the entity. ${ }^{11}$ In the tradition of the Cisbaikalian Buryats there still exists the archaic custom of incorporation of a newborn into a socium through a special ritual. ${ }^{12}$

Since ancient times Mongols have formed the stone heaps decorated with trees (oboo) at the tops of sacred mountains and on mountain passes. These cult objects were polyfunctional objects. They marked clan and ethnic territory, and simultaneously represented both a sanctuary and a sacrifice. The appearance of the obo resembles a mountain and is the symbol of axis mundi. The oboo cult and its evolution and transformation were thoroughly described by C. R. Bawden (1958) and M. Tatar (1971).

The status of holy place was not exclusively ascribed to prominent natural objects. Archeological monuments also enjoyed this status. Inner Asia is extremely rich in such places: ancient cave drawings, petroglyphs, burial grounds marked by stone sculptures ( $x \ddot{u ̈ n ~ c ̌ u l u u), ~ d e e r ~ s t o n e s ~(b u-~}$ gan хоร̌oo, xeregsü̈̈r), and ruins of ancient fortifications and towns such as earthworks and stone walls. These places were revered by nomads as manifestations of divine power or traces of mythical people from previous cultures who, fearing the prophecies, had abandoned these places or buried themselves alive. For instance, petroglyphic drawings on hard-to-reach cliffs at Aya harbor were considered the work of deities who chose the cliffs as their canvas.

Numerous sacred loci of nomadic living space were associated with the key stages of life cycle - birth and death. A burial place in the Mongolian tradition is always located in the clan's land (ovogin omčit gazar) (Ochir and Galdanova 1988: 124). One of the allegorical terms denoting burial (niutagžuulxa 'to send to homeland') directly references this fact. Usually dry southern mountain slopes were chosen as burial place.

The clan territory included places where children's afterbirths were buried. The afterbirth burial ritual in the tradition of partial sedentarism was characterized by the highest ritual complexity. ${ }^{13}$ Among the nomads, the afterbirth could either be buried under a heap of cinders near a yurt, on a tree in a forest, or in an abandoned hole (Badashkeeva 2000), or it could be dried and carried everywhere as a family relic (Galdanova 1987: 61). In either case, the custom of honoring the afterbirth (toonto taxixu or huurida mürgexe), was observed everywhere in the Mongolian world, demonstrating a close association with the reverence of the homeland. As a child grew older, the Mongols would show him or her the approximate place on some of the camping grounds of the nomadic cycle, where the afterbirth was buried. It was the place where he or she was born - unasan gazarta. Among the Buryats this ritual was usually performed at the 
hyypu winter settlement in the xoimor of the yurt. Each person had to know the place where his or her afterbirth was buried and honor it. So the connection with this place, or the clan's land, was the crucial prerequisite of well-being.

Hunters had their own sacred places in their hunting grounds where they offered sacrifices to the god of the taiga and to local guardian spirits asking for rich spoils of the chase.

Traditionally, certain taboos were observed in relation with the cult places. The lands around the sanctuaries were accorded 'reserved' status. This meant the prohibition of all economic activity - sertei, aixa (Buryat), or xorig gazar (Mongolian). In these places it was forbidden to hew trees, tear grass, and dig earth, move stones, or hunt. Women and aliens (representatives of an alien family, including foreigners) were banned from the sacred place to prevent them from angering the spirits and getting themselves into trouble. The aggregate of the above-mentioned places formed centers and boundaries of clannish, tribal, or tribal union's territories.

The places associated with Chinggis-Khan's life and deeds act as sacral symbols reflecting a higher level of conscience - political conscience, i.e. self-ascription to a certain political entity. The entire expanse of the Mongolian world nowadays is replete with symbols of his presence, including the territories of Inner Mongolia and Buryatia. The interfluve area of the Onon and Kerulen rivers and, especially, the Burkhan-Khaldun holy mountain - an ideologically important place in the making of Temujin (Allsen 1996) - act as the central sacred locus.

The image of a nomad whose life is not bound to the land and who easily changes habitation areas is entrenched in works on the topic of Mongolian studies. In reality, however, this reflects only certain stages in the history of the Mongolian peoples, connected with periods of change from a nomadic-communal structured society to the military-nomadic social formation. The rule of Chinggis-Khan presents the most illustrative example of such transformations and their after-effects. He carried out drastic reforms aimed at breaking up clannish and tribal connections in nomadic communities, mostly among hostile tribes. The destruction of kin relationships in a tribe was carried out in parallel with the breaking of the ties between community and ancestral lands (forced resettlement). The highest mercy his closest lieutenants could ask Chinggis-Khan for was the right to reunite with their kin. Ba'urči (steward/dapifer) Önggür asked for reunion with his native Baya'ud tribe (Cleaves 1982: 154; Rachewiltz 2004: 144-145). Narin To'oril begged permission to bring together his negüs brothers (Cleaves 1982: 158). In a commentary on $\S 213$ of the Secret history of the Mongols Rachewiltz provides an explanation why the Baya'uds were scattered (Rachewiltz 2004: 799). 


\section{CONCLUSION}

As we have demonstrated, the space settled and exploited by the various ethnic entities of the Mongolian world represents a highly complex system of specialized spaces. The dynamic utilization of space presupposes the division of the settlement area into segments where concrete economic activity is carried out (getting animal yield, fattening of cattle, hunting, harvesting); with characteristic types of pastures and climatic conditions relevant to that type of economic activity. In parallel with the practical development of the territories, each segment of space occupied its place in the religious and mythological system. The sacral map of space is filled with hierarchically different sacred loci. These are the family, clan, and tribal sanctuaries where annual rituals aimed at harmonization of relationships between society and nature were held. They are also the hierophany places and burial grounds of kinfolk and shamans. Boundaries form the common feature of all space clusters. They are manifested through various natural and cultural objects. The nomadic lifestyle determines a high degree of space exploitation since it includes a higher number of the markers of cultural human environment and provides their even distribution within the borders of the entire living space of the nomads.

\section{NOTES}

* This study has been supported by the mega-grant of the Government of Russian Federation (\# № 14.W03.31.0016) 'Dynamics of peoples and empires in Inner Asia'.

${ }^{1}$ For example, starting on a long trip, a man had to first proceed in the northwesterly direction: this cardinal direction was considered 'good' for men in a similar fashion to the male half of a yurt. It was customary to place a tether for colts and young camels on that side. By contrast, the southeasterly direction, which corresponded to the female half of a yurt, was considered bad. People threw away ash from the hearth in that direction because they considered it 'dead' (Tserenkhand 1993: 34).

${ }^{2}$ Yber is a polysemous term in Mongolian languages. It has the following meanings: a front or sunny side; a bosom, a chest; a southern sunny mountain slope overgrown with steppe vegetation, treeless clearings on dry slopes of light taiga (Melkheev 1969: 98).

${ }^{3}$ Spring migration of birds from the south is associated with a whole set of positive meanings. The most important of them are the beginning of the warm season and the return of the birds. Both Mongols and Turks welcomed the arrival of migratory birds, especially of the earliest group, as they widely opened the yurt's doors saying 'may happiness come in' (Butanaev and Mongush 2005: 69). Buryats observed the state of the arriving birds. If they appeared fat and flew low, people said the birds brought happiness (Khangalov 1960: 70). Birds flying away in autumn, by contrast, could take happiness away with them, hence the Mongols prohibited following them with the eyes (Erdenebold 2012: 72) and the Khakas even ran into their dwellings and covered their heads with fur-coats to stop hearing birds' cries.

${ }^{4}$ I. A. Manzhigeev noted that up until the 1917 revolution even the very scope of geographical beliefs of shamanistic Buryats was much too limited. Some of them believed Lake Baikal was the world's edge and the rare lucky ones who visited its 
shores acquired a 'right' to shamanize, or 'cure'. This applied for example to 'curing' erysipelas by striking sparks out of flint (Manzhigeev 1960: 10).

${ }^{5} \mathrm{R}$. Hertz wrote on this aspect of archaic conscience. He insists on the cultural sense of prevalence of the right through which a man creates a system of coordinates homologizing macro- and microcosm (Hertz 1909).

${ }^{6}$ In Mongolian fairy tales the subjects from the northern part are called 'our people', i.e. blood kin of the khan, whereas people from the southern part/region are called simply 'subjects' or 'tumen'.

${ }^{7}$ The beliefs of western Buryats demonstrate evidence of the conceptualization of lands located behind/northward as 'internal'. The meaning of the dream in which birds migrating south augur cessation of ongoing epidemics (Center for Oriental Manuscripts and Xylographs of the IMBTS SB RAS (hereinafter - COMX). F.14. Op.1. D.16). Similar beliefs were noted among the Tofalars (Melnikova 1994: 129).

${ }^{8}$ Such an image of mountains is represented in a ubiquitous Buryat legend cycle about Mongolian Sokhor-noyon representing the experience of nomadic interpretations of landmark characteristics of a landscape. Based on visual impressions, Sokhor-noyon determined advantages and disadvantages of a locality, foretelling the fortune and character of the people who would settle down in that place in the future (Tale about Sokhor-noyon. COMX, F. 14, Op. 1, D. 14).

${ }^{9}$ Rigid orientation of the Siberian autochthones toward procurement of furs resulting from the tribute policy of the Russian Empire in the course of 150-200 years led to a complete change of indigenous economic activity in Siberia 'having thrown away' the branches of the traditional economy not associated with hunting. The fur specialization became a factor in the social and economic regression of Siberian aboriginal peoples (Sherstova 2005: 95-100).

${ }^{10}$ In Buryat mythological beliefs larch is associated with a male, and pine tree with a female. 'According to the beliefs of Olkhon Buryats, after death the haadazma хун (man with a quiver - a male) turns into a larch, hаншигта хун (female) - into a pine tree' (Zhamtsarano 2001: 109).

${ }^{11}$ The sacred mountain is associated with the elder of the clan, the tribe with whom they are consulting, asking permission to perform any action.

${ }^{12}$ The head of the family with a first-born son must climb the sacred mountain and sacrifice a sheep to the ancestors and guardian spirits of the area. He adds a new stone to the heap of stones near the sacrificial altar. The stone symbolizes the soul of the newborn boy. In this way the sacral center 'gets acquainted' with the new tribal member and takes him under its 'patronage' (Field materials of the authors, 2000-2005).

${ }^{13}$ For instance, among Buryats, Yakuts, and Evenki.

\section{REFERENCES}

Allsen, T. 1996. Spiritual Geography and Political Legitimacy in the Eastern Steppe. In Claessen, H. J. M., and Oosten, J. G. (eds.), Ideology and the Formation of Early States (pp. 116-135). New-York: Brill.

Anichkov, E. V. 1914. Paganism and the Ancient Rus'. Saint Petersburg: M. M. Stasyulevich's Typ. Original in Russian (Аничков, Е. В. Язычество и древняя Русь. М.: Тип. М. М. Стасюлевича).

Badashkeeva, T. T. 2000. Toonto Tahihu: Symbols and Meaning. In Vanchikova, Ts. P. (ed.), The Culture of Central Asia: The Written Sources. Issue 4 (pp. 
153-164). Ulan-Ude: BNTs SO RAN. Original in Russian (Бадашкеева, T. T. Тоонто тахиху: символика и значение. Культура Центральной Азии: письменные источники / Ред. Ц. П. Ванчикова. Вып. 4, с. 153-164. УланУдэ: БНЦ СО РАН).

Bakaeva, E. P., and Sangadzhiev, Yu. I. 2005. The Culture of the Dwelling: Ethnic Traditions and Contemporary Priorities of the Kalmyks. Elista: Dzhangar. Original in Russian (Бакаева, Э. П., Сангаджиев, Ю. И. Культура жилища: этнические традиции и современные приоритеты у калмыков. Элиста: Джангар).

Baldaev, S. P. 1959. Buryat Wedding Rituals. Ulan-Ude: Buryat Book Publ. Original in Russian (Балдаев, С. П. Бурятские свадебные обряды. УланУдэ: Бурятское книжное издательство).

Barfield, T. J. 1992. The Perilous Frontier: Nomadic Empires and China. 221 BC. to A.D. 1757. Cambridge, Mass, and Oxford: Blackwell.

Barfield, T. J. 2001. The Shadow Empires: Imperial State Formation along the Chinese-Nomad Frontier. In Alcock, S. E., D'Altroy, T. N., Morisson, K. D., and Sinopoly, C. M. (eds.), Empires: Perspectives from Archaeology and History (pp. 10-41). Cambridge: Cambridge University Press.

Bawden, C. R. 1958. Two Mongol Text Concerning Obo-Worship. Oriens Extremus 5 (1): 23-41.

Beffa, M.-L., and Hamayon, R. 1983. Les categories mongoles de l'espace. Etudes mongoles et siberiennes, centrasiatiques et tibetaines 83 (14): 81-119.

Braudel, F. 1994. A History of Civilization. New York: Penguin Press.

Butanaev, V. Ya., and Mongush, Ch. V. 2005. Archaic Customs and Rites of the Sayan Turks. Abakan: Khakassian State University Press. Original in Russian (Бутанаев, В. Я., Монгуш, Ч. В. Архаические обычаи и обряды саянских тюрков. Абакан: Издательство Хакасского государственного университета).

Burchina, D. A. 1990. The Geser Heroic Epic of Western Buryats. A Guide to Poems and their Variants. Novosibirsk: Nauka. Original in Russian (Бурчина Д. А. Гэсэриада западных бурят. Указатель произведений и их вариантов. Новосибирск: Наука).

Dashibalov, B. B. 1995. Archaeological Monuments of the Qurykans and the Khori. Ulan-Ude: BNC SO RAN. Original in Russian (Дашибалов, Б. Б. Apхеологические памятники курыкан и хори. Улан-Удэ: БНЦ СО РАН).

Di Cosmo, N. 1994. Ancient Inner Asian Nomads: Their Economic Basis and its Significance in Chinese History. Journal of Asian Studies 53 (4): 1092-1126.

Di Cosmo, N. 2015. Why Qara Qorum? Climate and Geography in the Early Mongol Empire. Archivum Eaurasiae Medii Aevi 21: 67-78.

Dybo, A. V. (ed.) 2008. Natural Environment and Material Culture of the ProtoTurkic Peoples. Moscow: Vostochnaya literatura. Original in Russian (Дыбо, А.В. (ред.). Природное окружение и материальная культура пратюркских народов. М.: Восточная литература).

Egorov, V. L., and Zhukovskaya, N. L. 1979. Dwelling of the Population of the Mongolian People's Republic. In Cheboksarov, N. N. (ed.), The Types of Traditional Rural Dwellings of the Peoples of South-East, East and South Asia (pp. 
98-215). Moscow: Nauka. Original in Russian (Егоров, В. Л., Жуковская, Н. Л. Жилище населения Монгольской народной республики. В: Чебоксаров, Н. Н. (ред.), Типь традииионного сельского жилища народов ЮгоВосточной, Восточной и Южной Азии, с.198-215. М.: Наука).

Erdenebold, L. 2012. Traditional Beliefs of the Oirat Mongols (the Late $19^{\text {th }}$ Early 20 $0^{\text {th }}$ Century). Ulan-Ude: BNC SO RAN. Original in Russian (Эрдэнэболд, Л. Традищионные верования ойрат-монголов (конеи XIX начало ХХ в.). Улан-Удэ: БНЦ СО РАН).

Fernandez-Gimenez, M. E. 2000. The Role of Mongolia Nomadic Pastoralists' Ecological Knowledge in Rangeland Management. Ecological Applications 10 (5): 1318-1326.

Gold, J. R. 1980. An Introduction to Behavioral Geography. Oxford: Oxford University Press.

Golovnev, A. V. 1995. Talking Cultures. Samoyed and Ugric Traditions. Ekaterinburg: UrO RAN. Original in Russian (Головнев, А. В. Говорящчие культуры. Традиции самодиицев и угров. Екатеринбург: УрО РАН).

Hertz, R. 1909. La prééminance de la main droil. Étude sur la polarité religieuse. Revue Philosophique de la France et de l'Étranger 68: 553-580.

Humphrey, C. 1974. Inside a Mongolian Tent. New Society 30: 273-275.

Jenkins, G. 1974. A Note on Climatic Cycles and the Rise of Chinggis Khan. Central Asiatic Journal 18 (4): 217-226.

Khasanov, A. M. 1984. Nomads and Outside World. Cambridge - New York: Cambridge University Press.

Khasanov, A. M. 2008. Nomads and the Outside World. Saint Petersburg: Filologicheskij fakultet SPbGU. Original in Russian (Хазанов, А. М. Кочевники и внешний мир. СПб: Филологический факультет СПбГУ).

Kradin, N. N. 2002. Nomadism, Evolution and World-Systems: Pastoral Societies in Theories of Historical Development. Journal of World-Systems Research 8 (3): $368-388$.

Kudryavtsev, F. A. 1940. The History of the Buryat-Mongolian People (from the $17^{\text {th }}$ Century to the 1860s). Moscow - Leningrad: AN SSSR Press. Original in Russian (Кудрявцев, Ф. А. История бурят-монгольского народа (от XVII в. до 60-х XIX в.). Очерки. М. - Л.: АН СССР).

Kyzlassov, L. R. 1960. Tuva at the Time of the Turkic Khaganate. Vestnik Moskovskogo Universiteta. Series 9. Istoricheskie nauki 1: 51-76. Original in Russian (Кызласов, Л. Р. Тува в период тюркского каганата. Вестник Московского университета. Серия 9. Исторические науки 1: 51-76).

Kyzlassov, I. L. 2008. Materials for the Early Turkic History. Ancient Turkic Dwellings. In Dybo, A. V. (ed.), The Natural Environment and Material Culture of the Pre-Turkic Peoples (pp. 273-341). Moscow: Vostochnaya literatura. Original in Russian (Кызласов, И. Л. Материалы к ранней истории тюрок. Древнетюркские обиталища. В: Дыбо, А. В. (ред.), Природное окружение и материальная культура пратюркских народов, с. 273-341. М.: Восточная литература).

Leroi-Gourhan, A. 1965. Le geste et la parole. II. La Mémoire et les rythmes. Paris: Albin Michel. 
Maidar, D., and Darisüren, L. 1976. Home. The History of Dwelling. Ulaanbaatar: Ulsyn khevleliin gazar. Original in Mongolian (Майдар, Д., Дарьсурэн, Л. Гэр. Орон сууины түҮхэн тойм. Улаанбаатар: Улсын хэвлэлийн газар).

Malov, S. E. 1959. The Ancient Turkic Written Monuments of Mongolia and Kirghizia. Moscow - Leningrad: AN SSSR. Original in Russian (Малов, C. Е. Памятники древнетюркской письменности Монголии и Киргизии. М. Л.: АН СССР).

Manzhigeev, I. M. 1960. The Yangut Buryat Clan (an Experience of Historical and Ethnographic Study). Ulan-Ude: Buryat Book Publ. Original in Russian (Манжигеев, И. М. Янгутский бурятский род (опыт историкоэтнографического исследования). Улан-Удэ: Бурятское книжное издательство).

Marin, A. 2010. Riders under Storms: Contributions of Nomadic Herders' Observations to Analyzing Climate Change in Mongolia. Global Environmental Change 20: 162-176.

Melnikova, L. V. 1994. Tofy: Historical and Ethnographic Essay. Irkutsk: VostochnoSibirskoye Knizhnoye Izdatel'stvo. Original in Russian (Мельникова, Л. В. Toфы: историко-этнографический очерк. Иркутск: ВСКИ)

Melkheev, M. N. 1969. Toponymy of Buryatia. Ulan-Ude: Buryatskoye Knizhnoye Izdatelstvo. Original in Russian (Мельхеев, М. Н. Топонимика Бурятии. Улан-Удэ: Бурятское книжное издательство).

Menes, G. 1992. Materials on the Traditional Funeral Rites of Zakhchins of the Mongolian People's Republic in the Late $19^{\text {th }}-$ Early $20^{\text {th }}$ Century. In Gerasimova, K. M. (ed.), The Traditional Rituals of the Mongol Peoples (pp. 112127). Novosibirsk: Nauka. Original in Russian (Мэнэс, Г. Материалы по традиционной похоронной обрядности захчинов МНР конца XIX в. начала ХХ в. Традиционная обрядность монгольских народов / Ред. К. М. Герасимова, с. 112-127. Новосибирск: Наука).

Ochir, A., and Galdanova, G. R. 1988. The Traditional Family Ritualism of the Mingats of the Mongolian People's Republic. In Basayeva, K. D., and Nimayev, D. D. (eds.), The Cultural and Everyday Traditions of the Buryats and Mongols (pp. 109-128). Ulan-Ude: BNC SO RAN. Original in Russian (Очир, А., Галданова, Г. Р. Традиционная семейная обрядность мингатов МНР. В: Басаева, К. Д., Нимаев, Д. Д. (ред.), Культурно-бытовые традиции бурят и монголов, с. 109-128. Улан-Удэ: БНЦ СО РАН).

Podosinov, A. V. 1999. Ex oriente lux! The Cardinal Points Orientation in Archaic Cultures of Eurasia. Moscow: Yazyki russkoj kultury. Original in Russian (Подосинов, А. В. Ex oriente lux! Ориентащия по странам света в архаических культурах Евразии. М.: Языки русской культуры).

Potanin, G. N. 1883. Essays on Northeastern Mongolia. Issue 4. Ethnographic materials. Saint Petersburg: V. Kirshbaum. Original in Russian (Потанин, Г. Н Очерки Северо-Западной Монголии. Выпуск 4. Материалы этнографические. СПб.: В. Киршбаум).

de Rachewiltz, I 2004. The Secret History of the Mongols. A Mongolian Epic Chronicle of the Thirteenth Century. Vol 1. Leiden - Boston: Brill. 
Rintchen, B. 1959. Les matériaux pour l'étude du chamanisme mongol. 1. Asiatische Forschungen 3. Wiesbaden: O. Harrasovitz.

Sherstova, L. I. 2005. Turkic Peoples and Russians in South Siberia. Novosibirsk: IAE SO RAN. Original in Russian (Шерстова, Л. И. Тюрки и русские в Южной Сибири. Новосибирск: ИАЭ СО РАН).

Skorodumova, L. G. 2004. The Mongolian Language: Images of the World. Ulaanbaatar: Bembi San. Original in Russian (Скородумова, Л. Г. Монгольский язык: образы мира. Улан-Батор: Бемби Сан).

Solomatina, S. N. 2007. River in Mythical and Ritualistic Tradition of the Tuvinians. In Pavlinskaia, L. R. (ed.), Rivers and Peoples of Siberia (pp. 158-172). Saint Petersburg: Nauka. Original in Russian (Соломатина, С. Н. Река в мифо-ритуальной традиции тувинцев. В: Павлинская, Л. Р. (ред.), Реки и народы Сибири (с. 158-172). СПб.: Наука).

Sosnovsky, G. P. 1940. To the History of Cattle Breeding in Siberia. In Komarov, V. L. (ed.), The Issues of Origin, Evolution and Breeding of Domestic Animals. Vol. 1 (pp. 135-149). Moscow - Leningrad: AN SSSR. Original in Russian (Сосновский, Г. П. К истории скотоводства в Сибири. В: Комаров В. Л. (ред.), Проблемы происхождения, эволючии и породообразования домашних жсивотных. Т. 1, с. 135-149. М. - Л.: АН СССР).

Skrynnikova, T. D. 2005. Images of Earth and Sky of the Medieval Mongols. In Zamyatin, D. N. (ed.), Humanitarian Geography. Scientific and CulturalEducational Almanach. Vol. 2 (pp. 37-54). Moscow: Institut Naslediya. Original in Russian (Скрынникова, Т. Д. Образы земли и неба у средневековых монголов. В: Замятин, Д. Н. (ред.), Гуманитарная география. Научный и культурно-просветительский альманах. Вып. 2, с. 37-54. М.: Институт Наследия).

Tatar, M. 1971. Zur Fragen des Obo-Kultes bei den Mongolen. Acta Orientalia 24 (3): 301-330.

Trepavlov, V. V. 2005. The Ulus Substrate and the Imperial Substrate: Searching for the 'Nucleus' of Nomadic Statehood. In Bazarov, B. V., Kradin, N. N., and Skrynnikova, T. D. (eds.), The Mongol Empire and Nomadic World. Book 2 (pp. 71-86). Ulan-Ude: BNC SO RAN. Original in Russian (Трепавлов, В. В. Улусный субстрат и имперский субстрат: поиск 'ядра' кочевой государственности. В: Базаров, Б. В., Крадин, Н. Н., Скрынникова, Т. Д. (ред.), Монгольская империя и кочевой мир. Книга 2, с. 71-86. Улан-Удэ: БНЦ СО РАН).

Trepavlov, V. V. 2011. Sacral Topography of the Jochi Ulus. Etnograficheskoye obozrenie 2: 107-115. Original in Russian (Трепавлов, В. В. Сакральная топография улуса Джучи. Этнографическое обозрение 2: 107-115).

Tserensodnom, D. 2001. Traditional Methods of Research on Lands and Nomads. In Dialogue among Civilizations: Interaction between Nomadic and Other Cultures of Central Asia (pp. 481-482). Ulaanbaatar: IISNC. Original in Russian (Цэрэнсодном, Д. Традиционные методы исследования земель у кочевников. In Dialogue among Civilizations: Interaction between Nomadic and Other Cultures of Central Asia. Ulaanbaatar: IISNC).

Tserenkhand, G. 1993. The Nomadic Camping Ground Traditions of the Mongols. In Zoriktuyev, B. R. (ed.), From the History of Economy and Material Culture 
of the Turkic and Mongol Peoples (pp. 27-36). Novosibirsk: Nauka. Original in Russian (Цэрэнханд, Г. Традиции кочевого стойбища у монголов. В: Зориктуев, Б. Р. (ред.), Из истории хозяйства и материальной культуры тюрко-монгольских народов, с. 27-36. Новосибирск: Наука).

Tuan, Yi-Fu. 1974. Topophilia: A Study of Environmental Perception, Attitudes and Values. Englewood Cliffs, NJ: Prentice-Hall.

Tuan, Yi-Fu. 1990. Topophilia: A Study of Environmental Perception, Attitudes and Values. New York: Morningside.

Tuan, Yi-Fu. 2002. Space and Place: The Perspective of Experience. $9^{\text {th }}$ ed. Minneapolis - London: University of Minnesota Press.

Wasilewski, J. 1976. Space in Nomadic Cultures - a Spatial Analysis of Mongol Yurt. Altaica Collecta 9: 345-360.

Zhamtsarano, Ts. 2001. Travel Notes of 1903-1907. Ulan-Ude: BNC SO RAN. Original in Russian (Жамцарано, Ц. Путевые дневники 1903-1907 г2. Улан-Удэ: БНЦ СО РАН).

Zhukovskaya, N. L. 1988. Categories and Symbols of Traditional Mongolian Culture. Moscow: Nauka. Original in Russian (Жуковская, Н. Л. Категории и символика традиционной культуры монголов. М.: Наука).

\section{Archival Sources}

Batorov P. P. An additional application to Buryat cosmogony. Center for Oriental Manuscripts and Xylographs of the Institute for Mongolian, Buddhist and Tibetan Studies of the Siberian Branch of the Russian Academy of Sciences. Personal archival fund of P. P. Batorov 14, F. 14. Op. 1. D. 13. Original in Russian (Баторов П. П. Дополнительное приложение к космогонии бурят. Центр восточных рукописей и ксилографов ИМБТ СО РАН, Л. Ф. П. П. Баторова 14, Оп. 1, Д. 13).

Batorov P. P. A Tale about Sokhor-noyon. Center for Oriental Manuscripts and Xylographs of the Institute for Mongolian, Buddhist and Tibetan Studies of the Siberian Branch of the Russian Academy of Sciences. Personal archival fund of P. P. Batorov 14, Op. 1. D. 14. Original in Russian (Предание о Coхор-нойоне. Центр восточных рукописей и ксилографов ИМБТ СО РАН, Л. Ф. П. П. Баторова 14, Оп. 1, Д. 14).

Batorov P. P. A Prophetic Sign. Center for Oriental Manuscripts and Xylographs of the Institute for Mongolian, Buddhist and Tibetan Studies of the Siberian Branch of the Russian Academy of Sciences. Personal archival fund of P. P. Batorov 14, Op. 1. D. 14. Original in Russian (Предвещающая примета. Центр восточных рукописей и ксилографов ИМБТ СО РАН, Л. Ф. П. П. Баторова 14, Оп. 1, Д. 14).

\section{Informants}

Baskhaev G. V. 1931. Buura clan, Baitog village of the Ekhirit-Bulagat district of Irkutsk oblast (materials obtained in 2000-2005).

Altaev G. A. 1928. Buura clan, Baitog village of the Ekhirit-Bulagat district of Irkutsk oblast (materials obtained in 2000-2005). 